\title{
EFFECT OF PRE-TREATMENT AND AIR TEMPERATURE ON DRYING TIME OF CHERRY TOMATO
}

\author{
I. Doymaz ${ }^{1}$, A. S. Kipcak1,*
}

\begin{abstract}
The effects of pre-treatment and air temperature with on drying and rehydration characteristics of cherry tomato slices were studied. Drying experiments are carried out with the air temperature of 55,65 , and $75^{\circ} \mathrm{C}$. Drying time decreased with pre-treatment, and it also decreased considerably with increase in air temperature. The results indicated that the cherry tomatoes which were pre-treated with potassium solution were explored within the shortest time. Furthermore, superior rehydration was observed the samples which were pre-treated with potassium solution. The moisture effective diffusivity calculated from the second Fick's law of diffusion ranged from 2.26 to $6.22 \times 10^{-9} \mathrm{~m}^{2} / \mathrm{s}$ over the temperature range studied. Activation energy was estimated by an Arrhenius type equation and the activation energy values varied from 26.51 to $32.79 \mathrm{~kJ} / \mathrm{mol}$.
\end{abstract}

Keywords: Cherry tomato, Pre-treatment, Drying, Rehydration, effective moisture diffusivity, activation energy

\section{INTRODUCTION}

Tomato (Lycopersiconesculentum) is the second important vegetable cultivated throughout the world with a production at about 162 million tons and Turkey is the fourth biggest producer after China, India and USA at about 11.35 million tons [1, 2]. Cherry tomato (Lycopersiconesculentum var. Cerasiforme) is a kind of a small tomato used in the salad dressing. Since tomatoes deteriorate within 2-3 weeks after harvesting, it is very important to improve their shelf life and make the fruit available when not in season for this reason tomatoes are often dried and sold in a dehydrated form [3].

Drying is a classical method of food preservation that enables an extended shelf-life, lighter weight for transportation, and less space needed for storage. Even with the development of newer drying techniques, most vegetables are still air-dried because this method of dehydration is still the simplest and most economical [4]. A lot of data has been reported in the literature on the drying properties of various products such as cocoyam [5], yam [6], tomato [2, 7], and Jerusalem artichoke [8] and others. In some studies, the effect of pre-treatment on the drying rate or time of agricultural products has been reported by various authors. Potassium and sodium hydroxide, potassium meta bisulphate, potassium carbonate, methyl and ethyl ester emulsions, ascorbic and citric acids, the most common and commercially used some pre-treatments [9-14]. Pre-treatments prevents loss of colour by inactivating enzymes, reduce the drying time by relaxing tissue structure and yield a good quality dried product [9]. No work has been found detailing the effect of dipping with pre-treatments before drying of cherry tomato slices. The main objectives of this study were to investigate the effect of air temperature and pre-treatments on drying and rehydration characteristics, and compute effective moisture diffusivity and activation energy of cherry tomato slices.

\section{MATERIALS AND METHODS Materials}

Cherry tomatoes were obtained from a local supermarket in İstanbul. All samples of cherry tomatoes were cleaned with tap water to remove the dust and unwanted materials that will affect the experiments, then the surface moisture were removed using a paper towel. Two different pre-treatments were applied to the cherry tomatoes before drying, and untreated sample was used as a control. The details of pre-treatments are described in Table 1. After that the samples were cut into halves with the approximate diameter of $36.6 \mathrm{~mm}$. 
Table 1. List of pre-treatments

\begin{tabular}{|l|l|}
\hline Code & Description \\
\hline Potas & $\begin{array}{l}\text { The samples were pre-treated with solution of potassium carbonate }(3 \%)+\text { olive oil }(0.5 \%) \text { at } 20^{\circ} \mathrm{C} \\
\text { for } 2 \text { min. After pre-treatment, the samples were blotted with tissue paper to remove superficial } \\
\text { water. }\end{array}$ \\
\hline Citric acid & $\begin{array}{l}\text { The samples were pre-treated with solution of citric acid (1\%) at } 20^{\circ} \mathrm{C} \text { for } 2 \text { min. After pre-treatment, } \\
\text { the samples were blotted with tissue paper to remove superficial water. }\end{array}$ \\
\hline Control & The samples were no pre-treated with anything. \\
\hline
\end{tabular}

Moisture contents of the cherry tomatoes were determined using a method of AOAC [15]. For the method Ecocell LSIS-B2V/EC55 model incubator (MMM Medcenter Einrichtungen GmbH, Planegg, Germany) was used. Four parallel experiments for conducted and the average values of the moisture contents were calculated.

\section{Drying procedure}

Drying experiments were performed in a laboratory scale hot-air dryer, described previously by Doymaz (2004) [10] and installed in the Chemical Engineering Department of Yildiz Technical University, Istanbul, Turkey. Desired experiments conditions inside the dryer were obtained for at least $30 \mathrm{~min}$ prior to each run. Drying runs of tomato were conducted at three temperatures $\left(55,65\right.$, and $\left.75^{\circ} \mathrm{C}\right)$ with fixed airflow of $2.0 \pm 0.1 \mathrm{~m} / \mathrm{s}$ at atmospheric conditions. About $85 \pm 2$ grams of tomato slices were used for each run. Moisture loss was recorded at $30 \mathrm{~min}$ intervals during drying by means of a digital balance (Mettler-Toledo AG, Grefensee, Switzerland, model BB3000) with an accuracy of $\pm 0.1 \mathrm{~g}$. The drying was carried out to final moisture content of $10 \%$ from initial moisture content of about $93.8 \%$ (w.b.). After drying, all products were packed in polyethylene bags wrapped in aluminum foil to prevent light damage and stored at ambient temperature. Drying tests were triplicated at each air temperature and averages are reported.

\section{Mathematical modelling}

Cherry tomatoes' moisture content $(M)$, drying rate $(D R)$ and moisture ratio $(M R)$ were calculated using equations (1), (2) and (3), respectively:

$$
M=\frac{m_{w}}{m_{d}}
$$

where $M, \mathrm{~m}_{\mathrm{w}}$ and $\mathrm{m}_{\mathrm{d}}$ are the moisture content ( $\mathrm{kg}$ water / $\mathrm{kg}$ dry matter), water content $(\mathrm{g})$ and dry matter content (g), respectively.

$$
D R=\frac{M_{t+d t}-M_{t}}{d t}
$$

where $D R, M_{t+d t}$ and $t$ are the drying rate $(\mathrm{kg}$ water $/ \mathrm{kg}$ dry matter $\times \min )$, moisture content at $t+d t(\mathrm{~kg}$ water $/ \mathrm{kg}$ dry matter) and drying time (min), respectively.

$$
M R=\frac{M_{t}-M_{e}}{M_{i}-M_{e}}
$$

where $M R$ is the moisture ratio (dimensionless), $M_{t}, M_{e}$ and $M_{i}$ are the moisture content at selected time, at equilibrium and the initial value in $\mathrm{kg}$ water $/ \mathrm{kg}$ dry matter, respectively. The values of $M_{e}$ are relatively small compared to $M_{t}$ or $M_{i}$, hence the error involved in the simplification be assuming that $M_{e}$ is equal to zero is negligible [16]. 


\section{Determination of the effective moisture diffusivity}

The values of effective moisture diffusivity values were calculated according to the equation (4) given below:

$$
\ln (M R)=\ln \left(\frac{8}{\pi^{2}}\right)-\left(\pi^{2} \frac{\mathrm{D}_{\mathrm{eff}} t}{4 \mathrm{~L}^{2}}\right)
$$

Where $D_{\text {eff, }} L$ and $t$ are the effective moisture diffusivity $\left(\mathrm{m}^{2} / \mathrm{s}\right)$, the half-thickness of the slab (m), and the drying time (s), respectively. $D_{\text {eff }}$ can be calculated from the plot of $\ln (M R)$ versus $t$.

\section{Determination of the activation energy}

The effect of temperature on moisture diffusivity can be described by an Arrhenius-type equation [17]:

$$
D_{\text {eff }}=D_{0} \exp \left(-\frac{E_{a}}{R T}\right)
$$

where $D_{0}$ is the pre-exponential factor of the Arrhenius equation $\left(\mathrm{m}^{2} / \mathrm{s}\right), E_{a}$ is the activation energy for the moisture diffusion $(\mathrm{kJ} / \mathrm{mol}), R$ is the ideal gas constant $(\mathrm{kJ} / \mathrm{mol} \mathrm{K})$, and $T$ is the temperature in $(\mathrm{K})$. Eq. (9) can be rearranged into the form:

$$
\ln \left(D_{\text {eff }}\right)=\ln \left(D_{0}\right)-\frac{E_{a}}{R T}
$$

\section{Rehydration}

Rehydration experiments were carried out in distilled water bath at constant temperature of $25\left( \pm 1^{\circ} \mathrm{C}\right)$. Approximately $2.5 \mathrm{~g}$ of dried samples were added to $300 \mathrm{ml}$ distilled water, in a $400 \mathrm{ml}$ beaker. After rehydration (approximately $300 \mathrm{~min}$ ), samples were removed, blotted with tissue paper to eliminate excess water on the surface, and weighed. Weights of dried and rehydrated samples were measured using an electronic digital balance (Precisa, model XB220A, Precisa Instruments AG, Dietikon, Switzerland) having a sensitivity of $0.001 \mathrm{~g}$. The rehydration ratio $(R R)$ was calculated as follows [18]:

$$
R R=\frac{W_{r}}{W_{d}}
$$

where $W_{r}$ and $W_{d}$ are the weight after and before rehydration, respectively. Three repetitions were performed for each treatment and mean value was calculated.

\section{RESULTS AND DISCUSSION Drying Curves}

Figures 1, 2 and 3 show the effect of air drying temperature on the drying of cherry tomatoes. Drying curves are similar with the food products including fruits and vegetables drying studies. In the experiments studies, the drying times of untreated samples (control) needed for reaching the final moisture content are found as 1140 , 870 and $660 \mathrm{~min}$ for the air temperatures of 55,65 and $75^{\circ} \mathrm{C}$, respectively. The average drying rate of control samples increased 1.72 times, respectively, as air drying temperature increased from $55^{\circ} \mathrm{C}$ to $75^{\circ} \mathrm{C}$. Similar trend was observed for pre-treated samples at same temperatures. In the literature, it is explained that the higher heat absorption leads to higher product temperature, higher mass transfer driving force, faster drying rates and shorter drying times $[2,19,20]$. 


\section{Effect of dipping solution}

The effects of the dipping solution on changes in the moisture content of cherry tomato slices with drying time are shown in Figures 1, 2 and 3. The pre-treated samples dried faster than the control ones, thus confirming the fact that pre-treatment reduces the resistance to the movement of moisture thereby increasing the drying rate. The drying of control tomato slices took about 1140,870 and $660 \mathrm{~min}$ at 55,65 and $75^{\circ} \mathrm{C}$, respectively. Corresponding values for the pre-treated samples such as citric acid and potas codes were 1110, 780 and 630 min, and 900, 570 and $420 \mathrm{~min}$ at same temperatures, respectively. Pre-treatment solutions caused a decrease in the drying times by about 2.70-57.14\%. A similar effect of pre-treatment solution has been reported by Doymaz (2004) for apricots [10] and Kingsly et al. (2007) [9] for tomatoes.

\section{Effect of moisture diffusivity}

The effective moisture diffusivity values for different temperatures, calculated from Eq. (4), are given in Figure 4. It can be seen that the values of $D_{\text {eff }}$ increased greatly with dipping solution. Due to influence of dipping solution on internal mass transfer of tomato slices during drying, pre-treated samples had higher effective moisture diffusivity values. The diffusivity values of pre-treated and control samples found between 2.26 to $6.22 \times 10^{-9} \mathrm{~m}^{2} / \mathrm{s}$.

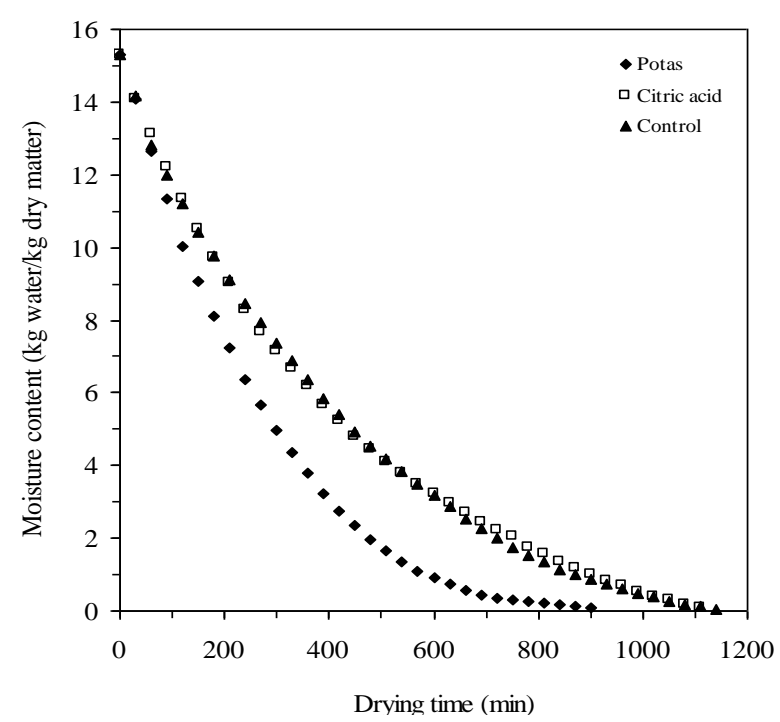

Figure 1. Changes in moisture content on a dry basis (kg water $/ \mathrm{kg}$ dry matter) during drying at $55^{\circ} \mathrm{C}$ for pretreated and untreated tomato slices

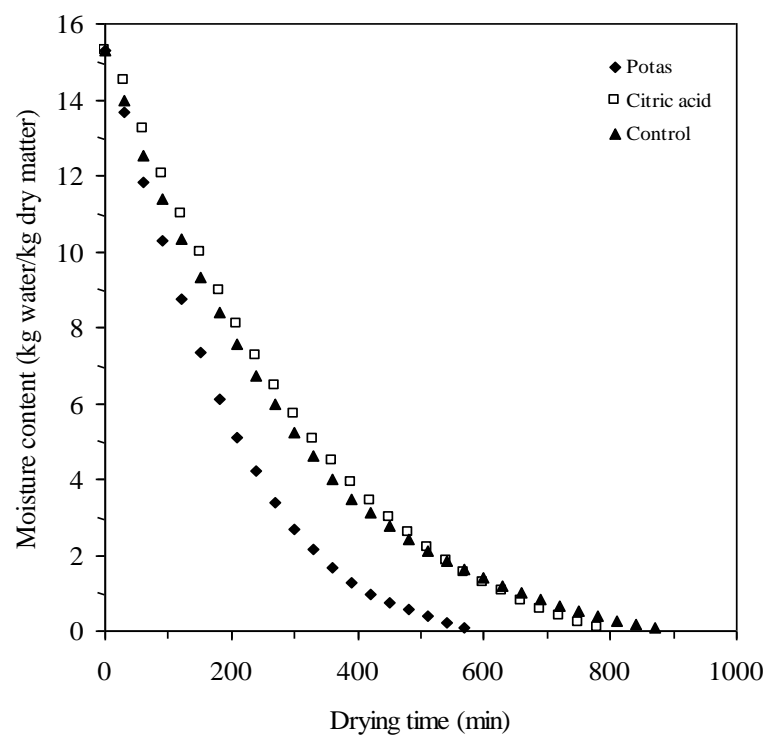

Figure 2. Changes in moisture content on a dry basis (kg water $/ \mathrm{kg}$ dry matter) during drying at $65^{\circ} \mathrm{C}$ for pretreated and untreated tomato slices 
The values reported herein are within the general range of $10^{-8}$ to $10^{-12} \mathrm{~m}^{2} / \mathrm{s}$ for biological materials [21]. The calculated values of $D_{\text {eff }}$ were in consistency with the values given in literature such as $2.3-9.1 \times 10^{-9} \mathrm{~m}^{2} / \mathrm{s}$ for tomatoes dried from $60^{\circ} \mathrm{C}$ to $110^{\circ} \mathrm{C}[22], 3.72-12.27 \times 10^{-9} \mathrm{~m}^{2} / \mathrm{s}$ for tomatoes dried from $45^{\circ} \mathrm{C}$ to $75^{\circ} \mathrm{C}$ [23], 5.13$10.26 \times 10^{-10} \mathrm{~m}^{2} / \mathrm{s}$ for tomato dried from 50 to $80^{\circ} \mathrm{C}$ [2], and $3 \times 10^{-10}$ and $5 \times 10^{-10} \mathrm{~m}^{2} / \mathrm{s}$ for cherry tomato by using convective drying [7]. The differences between the results can be explained by effect of type, slice thickness, composition, and tissue characteristics of the tomatoes and the proposed model used for calculation.

\section{Activation energy}

Temperature dependence of the effective moisture diffusivity values was described by an Arrhenius-type relationship. The activation energy was calculated by Eq. (6), and presented in Figure 5. Eqs. (8), (9), and (10) show the effect of temperature on $D_{\text {eff }}$ of the pre-treated and the control tomato slices with following coefficients:

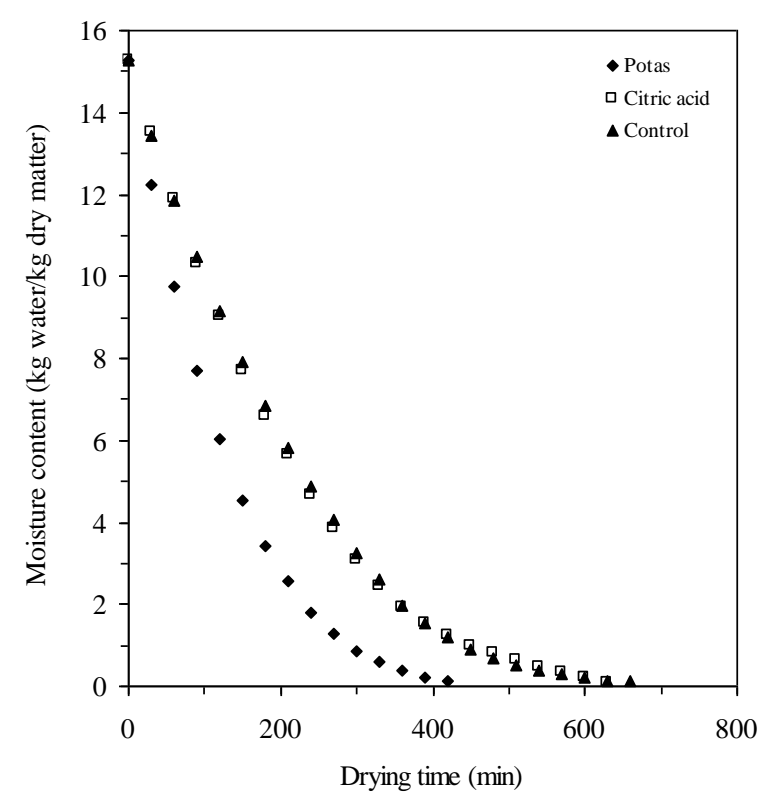

Figure 3. Changes in moisture content on a dry basis (kg water $/ \mathrm{kg}$ dry matter) during drying at $75^{\circ} \mathrm{C}$ for pretreated and untreated tomato slices

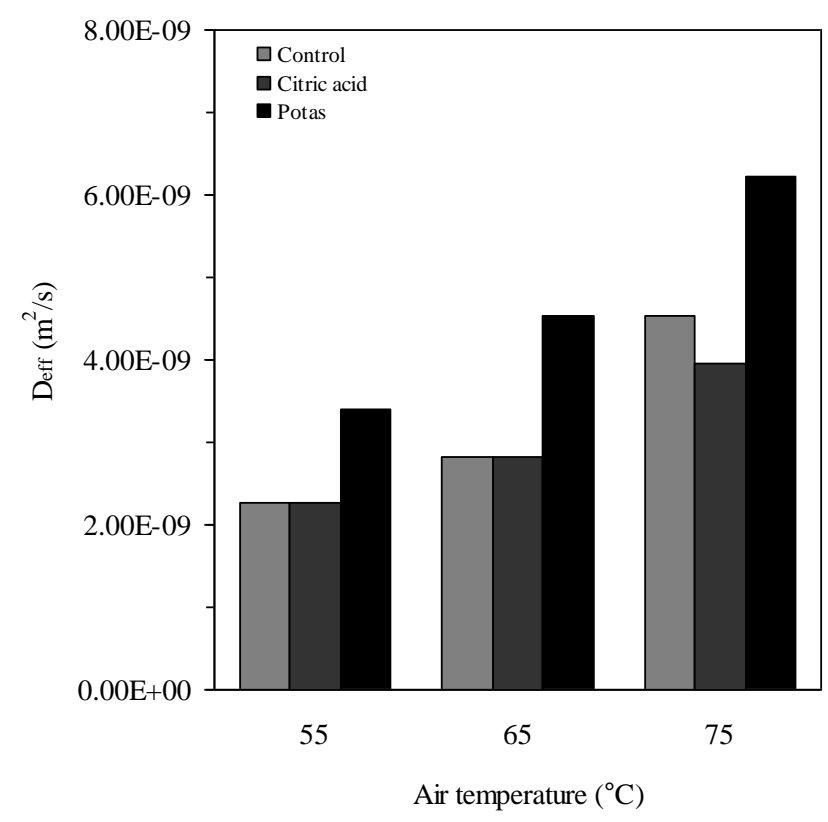

Figure 4. Variation of effective moisture diffusivity with air temperature 
Potas:

$$
D_{e f f}=1.280 \times 10^{4} \exp \left(-\frac{3460.6}{T}\right) \quad\left(R^{2}=0.9978\right)
$$

Citric acid:

$$
D_{\text {eff }}=3.687 \times 10^{5} \exp \left(-\frac{3189.4}{T}\right) \quad\left(R^{2}=0.9823\right)
$$

Control:

$$
D_{e f f}=3.600 \times 10^{4} \exp \left(-\frac{3944.4}{T}\right) \quad\left(R^{2}=0.9524\right)
$$

The activation energy values of potas, citric acid and control tomato slices found to be $28.77,26.51$ and $32.79 \mathrm{~kJ} / \mathrm{mol}$, respectively. The values of activation energy lie within the general range of $12.7-110 \mathrm{~kJ} / \mathrm{mol}$ for food materials [21]. The pre-treated tomato slices showed lower activation energy than the control samples. Pretreating of tomato slices resulted in a decrease in the activation energy require for mass diffusion during air drying.

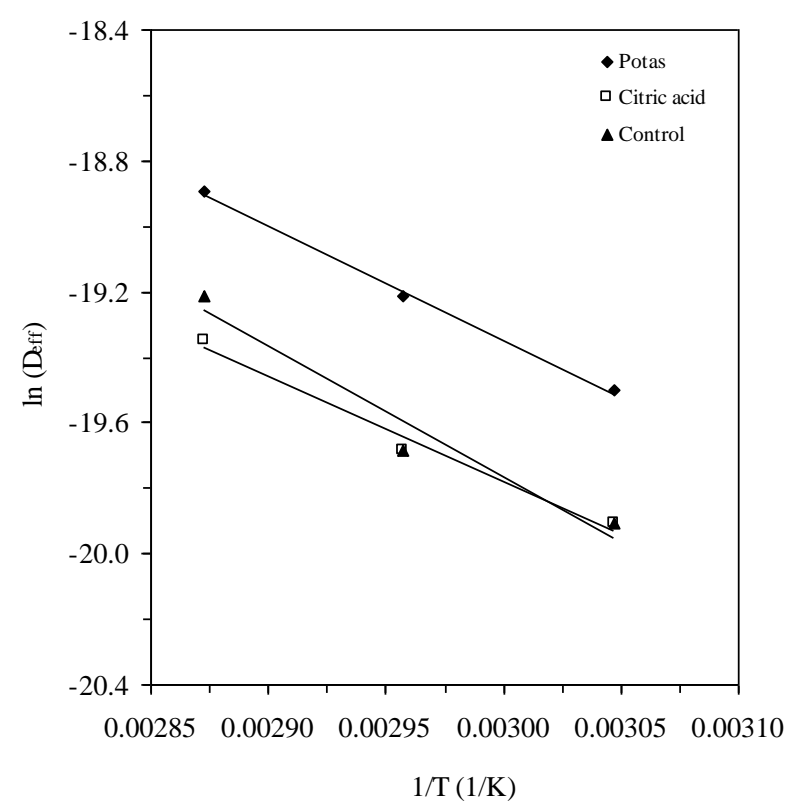

Figure 5. Arrhenius-type relationship between effective diffusivity and reciprocal absolute temperature

\section{Rehydration ratio}

Rehydration characteristics have been considered as a measure of the induced damage in the material during drying. The ability of food products to reconstitute depends primarily on the internal structure of the dried pieces and the extent to which the water-holding components (e.g., proteins and starch) have been damaged during drying [24]. The values of rehydration ratio of cherry tomato slices at different rehydration temperatures, calculated from Eq. (7) are shown in Figure 6. In the same figure, rehydration ratio was affected by the drying temperatures, since absorbed water decreased with temperature. As seen in Figure 6, the rehydration ratio of potas samples resulted in the highest rehydration, compared to citric acid and control samples. 


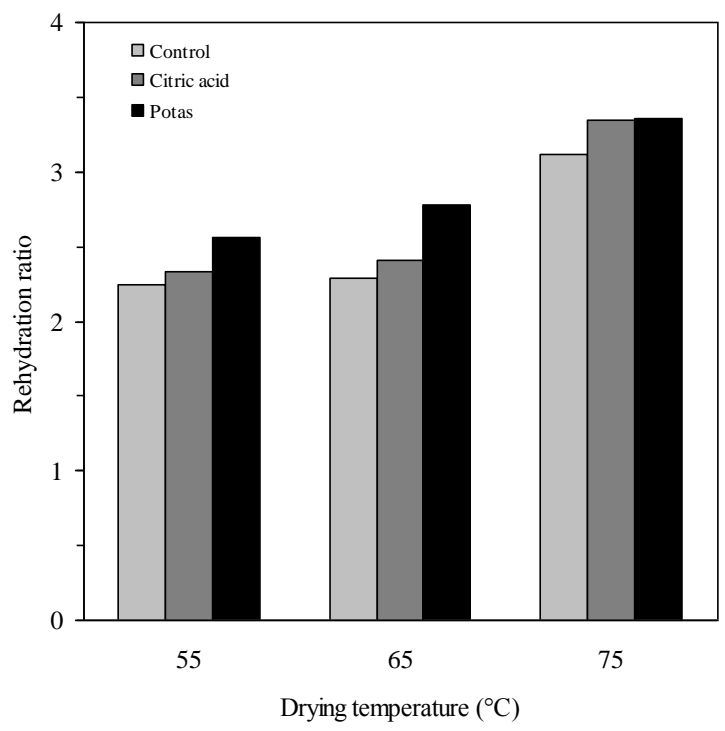

Figure 6. Effect of pre-treatment and air temperature on rehydration ratio of tomato slices

\section{CONCLUSION}

In the present study, the influence of pre-treatment and air temperature with on drying and rehydration characteristics of cherry tomato slices was investigated. According to the obtained results, it was seen that the air temperature and pre-treatment had more significant effects on drying and rehydration characteristics of tomato slices. The moisture effective diffusivity calculated from the second Fick's law of diffusion equation. The values of effective moisture diffusivity are found between $2.26 \times 10^{-9}$ and $6.22 \times 10^{-9} \mathrm{~m}^{2} / \mathrm{s}$ as temperature increased from 50 to $70^{\circ} \mathrm{C}$. The activation energy values of tomato slices were determined to be $28.77,26.51$ and $32.79 \mathrm{~kJ} / \mathrm{mol}$ for potas, citric acid and control codes, respectively, being similar to values reported for other vegetables.

\section{REFERENCES}

[1]FAO statistics database. Food and Agriculture Organization (FAOSTAT). http://www.fao.org/faostat/en/\#data/QC (Accessed August 04, 2014).

[2] Abano, E. E., Ma, H., \& Qu, W. (2012). Influence of combined microwave-vacuum drying on drying kinetics and quality of dried tomato slices. Journal of Food Quality, 35(3), 159-168.

[3] Izli, N., \& Isik, E. (2015). Color and microstructure properties of tomatoes dried by microwave, convective, and microwave-convective methods. International Journal of Food Properties, 18(2), 241-249.

[4] Ando, Y., Maeda, Y., Mizutani, K., Wakatsuki, N., Hagiwara, S., \& Nabetani, H. (2016). Impact of blanching and freeze-thaw pretreatment on drying rate of carrot roots in relation to changes in cell membrane function and cell wall structure. LWT - Food Science and Technology, 71, 40-46.

[5] Afolabi, T. J., Tunde-Akintunde, T. Y., \& Adeyanju, J. A. (2015). Mathematical modeling of drying kinetics of untreated and pretreated cocoyam slices. Journal of Food Science and Technology, 52(5), 2731-2740.

[6] Ju, H. Y., El-Mashad, H. M., Fang, X. M., Pan, Z., Xiao, H. W., Liu, Y. H., \& Gao, Z. J. (2016). Drying characteristics and modeling of yam slices under different relative humidity conditions. Drying Technology, 34(3), 296-306.

[7] Bennamoun, L., Khama, R., \& Léonard, A. (2015). Convective drying of a single cherry tomato: Modeling and experimental study. Food and Bioproducts Processing, 94, 114-123.

[8] Li, X., Guo, H., Yang, G., Zhang, Y., Zeng, Y., \& Shen, F. (2015). Thin-Layer Drying of Jerusalem Artichoke Tuber Slices and Sugar Conversion as Affected by Drying Temperature. Journal of Biobased Materials and Bioenergy, 9(4), 456-462.

[9] Kingsly, R. P., Goyal, R. K., Manikantan, M. R., \& Ilyas, S. M. (2007). Effects of pretreatments and drying air temperature on drying behaviour of peach slice. International Journal of Food Science and Technology, 42(1), $65-69$.

[10] Doymaz, I. (2004). Effect of pre-treatments using potassium metabisulphide and alkaline ethyl oleate on the drying kinetics of apricots. Biosystems Engineering, 89(3), 281-287. 
[11] Hiranvarachat, B., Devahastin, S., \& Chiewchan, N. (2011). Effects of acid pretreatments on some physicochemical properties of carrot undergoing hot air drying. Food and Bioproducts Processing, 89(2), 116127.

[12] Tunde-Akintunde, T. Y. (2014). Effect of pretreatments on drying characteristics and energy requirements of plantain (Musa aab). Journal of Food Pprocessing and Preservation, 38(4), 1849-1859.

[13] Pirone, B. N., De Michelis, A., \& Salvatori, D. M. (2014). Pretreatments Effect in Drying Behaviour and Colour of Mature and Immature "Napolitana" Sweet Cherries. Food and Bioprocess Technology, 7(6), 1640-1655. [14] Adiletta, G., Russo, P., Senadeera, W., \& Di Matteo, M. (2016). Drying characteristics and quality of grape under physical pretreatment. Journal of Food Engineering, 172, 9-18.

[15] Association of Official Analytical Chemists (AOAC). Official Methods of Analysis of AOAC International, 6th ed.; Virginia, 1995.

[16] Balbay, A., \& Şahin, Ö. (2012). Microwave Drying Kinetics of a Thin-Layer Liquorice Root. Drying Technology, 30(8), 859-864.

[17] Falade, K. O., \& Solademi, O. J. (2010). Modelling of air drying of fresh and blanched sweet potato slices. International Journal of Food Science and Technology, 45(2), 278-288.

[18] Taghian Dinani, S., \& Havet, M. (2015). Effect of voltage and air flow velocity of combined convectiveelectrohydrodynamic drying system on the physical properties of mushroom slices. Industrial Crops and Products, 70, 417-426.

[19] Alibas, I. (2013). Microwave, air and combined microwave-air drying of grape leaves (vitis vinifera 1.) and the determination of some quality parameters. International Journal of Food Engineering, 10(1), 69-88.

[20] Bal, L. M., Kar, A., Satya, S., \& Naik, S. N. (2010). Drying kinetics and effective moisture diffusivity of bamboo shoot slices undergoing microwave drying. International Journal of Food Science and Technology, 45(11), 2321-2328.

[21] Zogzas, N. P., Maroulis, Z. B., \& Marinos-Kouris, D. (1996). Moisture Diffusivity Data Compilation in Foodstuffs. Drying Technology, 14(10), 2225-2253.

[22] Akanbi, C. T., Adeyemi, R. S., \& Ojo, A. (2006). Drying characteristics and sorption isotherm of tomato slices. Journal of Food Engineering, 73(2), 157-163.

[23] Giovanelli, G., Zanoni, B., Lavelli, V., \& Nani, R. (2002). Water sorption, drying and antioxidant properties of dried tomato products. Journal of Food Engineering, 52(2), 135-141.

[24] Vega-Gálvez, A., Zura-Bravo, L., Lemus-Mondaca, R., Martinez-Monzó, J., Quispe-Fuentes, I., Puente, L., \& Di Scala, K. (2015). Influence of drying temperature on dietary fibre, rehydration properties, texture and microstructure of Cape gooseberry (Physalis peruviana L.). Journal of Food Science and Technology, 52(4), 23042311. https://doi.org/10.1007/s13197-013-1235-0. 